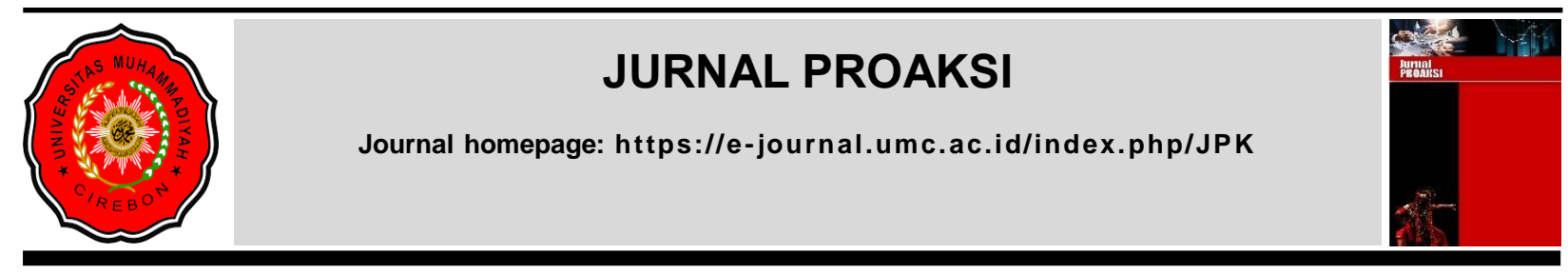

\title{
MODERASI PREFERENSI RISIKO PENGARUH PEMERIKSAAN PAJAK DAN PELAYANAN FISKUS TERHADAP KEPATUHAN WAJIB PAJAK
}

\author{
Alif Faruqi Febri Yanto', \\ Rida Perwita Sari* \\ ${ }^{1}$ Fakultas Ekonomi dan Bisnis, Universitas Pembangunan Nasional "Veteran" Jawa Timur \\ Email : aliffaruqi658@gmail.com \\ ${ }^{2}$ Fakultas Ekonomi dan Bisnis, Universitas Pembangunan Nasional "Veteran" Jawa Timur \\ *Corresponden Author : Email : ridaps.ak@upnjatim.ac.id
}

Diterima : 5 Agustus 2021

Direvisi : 20 Agustus 2021

Dipublikasikan : 17 Oktober 2021

\begin{abstract}
The percentage of individual taxpayer compliance both as a whole and non-employees and employees in 2018-2020 has decreased in the implementation of taxpayer compliance so that an evaluation must be carried out both in terms of policies and services. This study aims to obtain empirical evidence of the direct effect of taxpayer compliance which is influenced by tax audits and tax services and the moderating effect of risk preferences on the relationship between tax audits and tax service services on taxpayer compliance. The Pratama Surabaya Mulyorejo Tax Service Office is the object to be researched. Individuals as subjects and population with the type of probability sampling and simple random sampling method as many as 87 respondents. Analysis based on components or commonly known as Generalized Structured Component Analysis (GeSCA) is the analytical technique used in this research. The results of the output in the study explain that there is empirical evidence of taxpayer compliance which is directly influenced by tax audits and tax service services. Risk preferences can moderate the effect of tax audit on taxpayer compliance.
\end{abstract}

Keywords: Tax audit, tax service, risk preference and taxpayer compliance

\section{PENDAHULUAN}

Undang-undang perpajakan menjelaskan definisi pajak dari berbagai tipe diantaranya adalah pembayaran wajib kepada pemerintah Negara yang dibebankan oleh wajib pajak orang pribadi maupun badan usaha untuk membiayai pembangunan negara Resmi (2014). Sikap taat dalam menjalankan peraturan umum perpajakan yang ditandai dengan membayar dan melaporkan pajak tepat waktu merupakan pengertian dari kepatuhan wajib pajak Rahayu (2017). Menurut data laporan tahunan direktorat jenderal pajak dapat dijelaskan bahwa Indonesia memiliki angka kepatuhan wajib pajak yang diniliai masih dibawah standar yang diharapkan dalam segi membayar pajak maupun melaporkan pajak berupa SPT masa maupun dalam SPT tahunan ,masalah tersebut terjadi karena banyaknya penduduk di Indonesia yang sudah bekerja dan memiliki penghasilaln tetapi enggan mengukuhkan dirinya sebagai wajib pajak, tidak hanya itu para wajib pajak baik itu orang pribadi ataupun badan yang sudah terdaftar di kantor pajak terkait masih cenderung untuk menghindari bahkan lari dari kewajiban perpajakannya secara illegal atau melanggar peraturan perpajakan. Sehingga dapat mempengaruhi tingkat kepatuhan dalam menunaikan tugas perpajakannya. Pemaparan mengenai rasio wajib pajak yang patuh maupun tidak patuh dapat dilihat secara terperinci dalam diagram 1 mengenai rasio kepatuhan penyelenggaraan wajib pajak di Indonesia dalam dengan sisi melaporkan SPT selama periode 2015-2019. 


\section{Diagram 1.}

Rasio Kepatuhan Penyelenggaran Wajib Pajak di Indonesia Periode 2015-2019

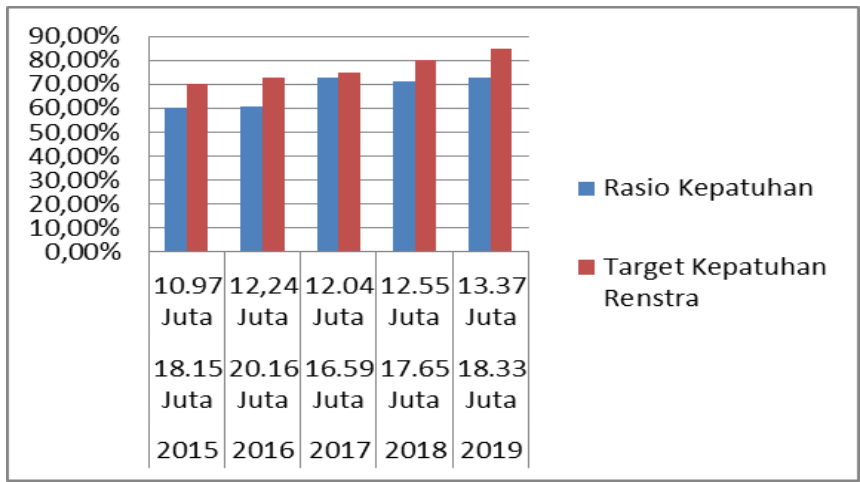

Sumber : Badan Pusat Statistik (Diolah)

Dari diagram tersebut dapat dijelaskan bahwa selama tahun 2015 hingga 2019 rasio kepatuhan wajib pajak selalu mengalami naik-turun sekitar $60 \%-75 \%$, jika dilihat dari aspek realisasi SPT selama periode 2015-2019 selalu terdapat jumlah wajib pajak yang tidak melaporkan SPT Tahunan tidak hanya itu selama periode 5 tahun tersebut masih banyak terdapat individu maupun suatu badan usaha yang dianggap sudah memiliki penghasilan,omset,laba tetapi tidak kunjung menunaikan kewajiban dalam mengukuhkan dirinya sebagai wajib pajak individu (OP) maupun wajib pajak Usaha operasional (badan) di kantor pajak terdekat bahkanhkan selama kurun waktu 5 (lima) tahun target realisasi dari rasio kepatuhan dalam menjalankan kewajiban perpajakan selalu dibawah target yang ditetapkan dalam rencana strategi direktorat jenderal pajak.

\section{Diagram 2.}

Rasio Kepatuhan Penyelenggaran Wajib Pajak di KPP Pratama Surabaya Mulyorejo Periode 20152020

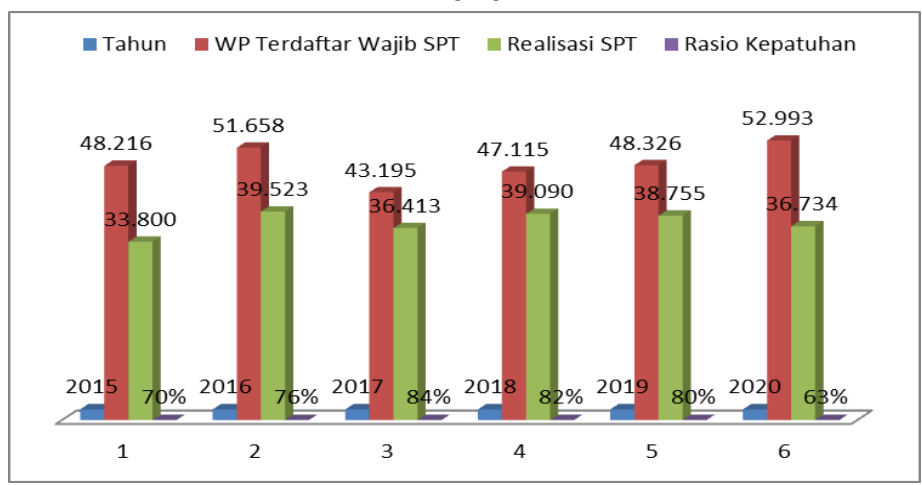

Sumber : KPP Pratama Surabaya Mulyorejo (Diolah)

Berdasarkan diagram 2 mengenai Rasio kepatuhan penyelenggaran wajib pajak di KPP Pratama Surabaya Mulyorejo terhitung pada periode 2015-2020 dijelaskan bahwa perbandingan rasio kepatuhan wajib pajak yang meliputi karyawan maupun non karyawan di kantor pajak Surabaya Mulyorejo dengan realisasi SPT selama 5 (lima) tahun terakhir, dimana realisasi SPT orang pribadi belum bisa mencapai jumlah wajib pajak yang terdaftar dan tingkat rasio kepatuhan wajib pajak menurun selama 3 tahun terakhir yaitu tahun 2018, 2019 hingga 2020 sebesar 82\%, 80\% dan 68\%, pemaparan tersebut dapat disimpulkan masih rendah nilai kepatuhan dalam menjalankan kewajiban perpajakan di kantor pajak Surabaya Mulyorejo tersebut, masalah tersebut disebabkan kurangnya minat wajib pajak dalam membayar dan melaporkan pajak terutang.

Pemerintah selaku direktorat jenderal pajak selalu berupaya untuk meningkatkan jumlah wajib pajak yang patuh dengan mengintensifkan program pemeriksaan pajak. Pemeriksaan pajak berdasarkan Peraturan Menteri Keuangan No.3 Tahun 2013 bertujuan sebagai alat untuk meningkatkan kepatuhan pemenuhan kewajiban perpajakan berdasarkan asas keadilan dan ketentuan umum perpajakkan (KUP). Kepatuhan wajib pajak akan terjadi jika sebagian wajib pajak baik orang pribadi maupun badan 
dilakukan pemeriksaan, menurut Dewi (2017) peningkatan nilai kepatuhan dalam menjalankan kewajiban perpajakan itu dipengaruhi secara signifikan oleh adanya penerapan pemeriksaan pajak, yang mana hasil dari temuan audit hasil pemeriksaan (audit findings) dapat dijadikan oleh Wajib Pajak sebagai pelajaran yang penting sehingga saat periode pajak berikutnya wajib pajak dapat segera memperbaiki kekurangan dalam menajalankan kewajiban perpajakan secara formal maupun material yang nantinya peningkatan intensitas pemeriksaan dapat meningkatkan hasil kepatuhan dalam menjalankan kewajiban perpajakan Mandagi (2014). Pelayanan aparat pajak yang baik juga dianggap memiliki peranan dalam meningkatkan kepatuhan wajib pajak, karena semakin baik pelayanan fiskus semakin tinggi pula kepercayaan masyarakat khususnya wajib pajak kepada fiskus sehingga dapat meningkatkan minat masyarakat dalam membayar maupun melaporkan SPT massa dan tahunan. Penelitian Yanto (2020) menjelaskan bahwa pelayanan fiskus dapat menumbuhkan sikap wajib pajak dalam memenuhi kewajiban maupun kepatuhan dalam menjalankan kewajiban perpajakannya. Preferensi risiko sebagai varibel moderasi juga dapat memperkuat maupun memperlemah dalam hal kepatuhan dalam melaksanakan kewajiban pajak, dikarenakan para banyak risiko yang harus dipertimbangkan oleh wajib pajak khususnya pribadi wajib pajak. Risiko-risiko tersebut antara lain, risiko keselamatan, social, keuangan, pekerjaan dan yang terakhir adanya risiko kesehatan. Ardyanto (2014) menjelaskan bahwa preferensi risiko dapat mempengaruhi tingkat dalam membayar dan melaporkan pajak.

Kepatuhan wajib pajak diteliti dengan menggunakan variabel independen pemeriksaan pajak, pelayanan fiskus memiliki hasil yang beragam diantaranya penelitian yang dilakukan oleh Mandagi (2014), Dewi (2017) dan Wahda (2018) menunjukkan bahwa pemeriksaan pajak berpengaruh terhadap tingkat kepatuhan dalam membayar dan melaporkan pajak. Variabel pelayanan fiskus juga terdapat perbedaan dimana pada penelitian Yuslina (2018), Nur (2020) dan Yanto (2020) menyimpulkan bahwa pelayanan fiskus berpengaruh positif terhadap kepatuhan dalam membayar dan melaporkan pajak, Penelitian Ardyanto (2014) dan Safitri (2018) menyatakan bahwa pelayanan fiskus yang dimoderasi oleh preferensi risiko berpangaruh terhadap kepatuhan dalam membayar dan melaporkan pajak, hal tersebut berbanding terbalik dengan penelitian dari Yuslina (2018), dan Nur (2020) menyatakan bahwa pelayanan fiskus yang dimoderasi oleh preferensi risiko tidak berpengaruh terhadap kepatuhan dalam membayar dan melaporkan pajak, fenomena tersebut menjadi dasar peneliti untuk melakukan penelitian ini. Penelitian ini mengembangkan beberapa penelitian sebelumnya sehingga peneliti tertarik untuk menambahkan variabel pemeriksaan pajak dengan dimoderasi oleh preferensi risiko yang diduga memiliki pengaruh yang signifikan terhadap wajib pajak dalam menjalankan kewajiban perpajakan. Uraian masalah tersebut dapat diambil tema penelitian dengan judul "Moderasi preferensi risiko pengaruh pemeriksaan pajak dan pelayanan fiskus terhadap kepatuhan wajib pajak".

\section{KAJIAN PUSTAKA}

\section{Teori Prospek}

Teori prospek dikenal dengan adanya istilah decision frame. Decision frame akan dibuat jika seseorang telah memperolah informasi yang cukup dalam pengambilan keputusan Kanheman dan Tversky (1979). Dalam pengambilan keputusan tersebut seseorang akan lebih memilih mana yang dirasa dapat menguntungkan dan memberikan peluang yang lebih besar serta membertimbangkan segala sesuatu secara rasional atau untung rugi Risk aversion terjadi apabila sesorang berada dalam posisi yang menguntungkan, sedangkan Risk seeking terjadi apabila seseorang lebih berani dalam menrima maupun menghadapi risiko. Preferensi risiko dijelaskan dalam teori prospek yang dianggap dapat berpengaruh terhadap wajib pajak dalam mengambil keputusan ketika melaksanakan perpajakannya, karena semakin tinggi risiko dalam membayar dan melaporkan pajak akan berdampak pada menurunnya tingkat kepatuhan wajib pajak, sebaliknya jika minimnya risiko dalam membayar pajak dapat menumbuhkan minat wajib pajak dalam menjalankan kepatuhan maupun kewajiban perpajakannya.

\section{Teori Atribusi}

Teori atribusi menyatakan bahwa bila individu mengamati perilaku orang lain, mereka mencoba untuk menentukan apakah itu ditimbulkan secara internal atau eksternal (Heider, 1958). Teori Atribusi relevan untuk menjelaskan Penelitian ini, sebab perilaku seseorang dalam memenuhi 
kewajiban perpajakan ditentukan oleh suatu keadaan, baik dari faktor eksternal misalnya sanksi pajak dan kualitas pelayanan, sedangkan dari faktor internal adanya pengetahuan wajib pajak mengenai perpajakan.

\section{Kepatuhan Wajib Pajak}

Kepatuhan wajib pajak berasal dari kata patuh yang merupakan taat dan patuh serta menjalankan kewajiban perpajakan, sesuai yang diatur dalam ketentuan umum perpajakan Resmi (2014).

\section{Pemeriksaan Pajak}

Definisi pemeriksaan pajak berdasarkan Pasal 1 ayat 2 PMK 03 No 82 Tahun 2011 mengenai Ketentuan dalam Pemeriksaan Pajak : "Pemeriksaan pajak merupakan kegiatan dalam mengolah bukti, temuanm data dan keterangan sehubungan dengan standar pemeriksaan guna mendapatkan bukti empiris terkait wajib pajak dalam menjalankan kewajiban perpajkannya berdasarkan peraturan yang tertuang dalam ketentuan umum perpajakan.

\section{Pelayanan Fiskus}

Fiskus merupakan aparat pajak yang bertugas untuk mengurus, membantu dan melakukan pemeriksaan terhadap wajib pajak orang pribadi maupun badan dalam menjalankan kewajiban perpajkannya Jatmiko (2006).

\section{Preferensi Risiko}

Preferensi risiko sangat berkaitan dengan teori prospek merupakan suatu keadaan dimana seseorang akan mengambil keputusan yang dinilai berpeluang maupun berdampak kerugian yang dilihat dari rasionalitas seseorang. Preferensi risiko sangat berkaitan dengan tingkat kepatuha wajib pajak, dimana wajib pajak akan memilih menghindari atau justru memilih risiko tersebut. Preferensi risiko dibagi menjadi berbagai macam jenis diantaranya, risiko kesehatan, risiko operasional, risiko pekerjaan, risiko keselamatan dan yang paling penting adalah risiko keuangan yang kuat hubungannya dengan tingkat wajib pajak dalam menjalankan kewajiban membayar dan melaporkan pajak berupa SPT tahunan maupun masa Aryobimo (2012).

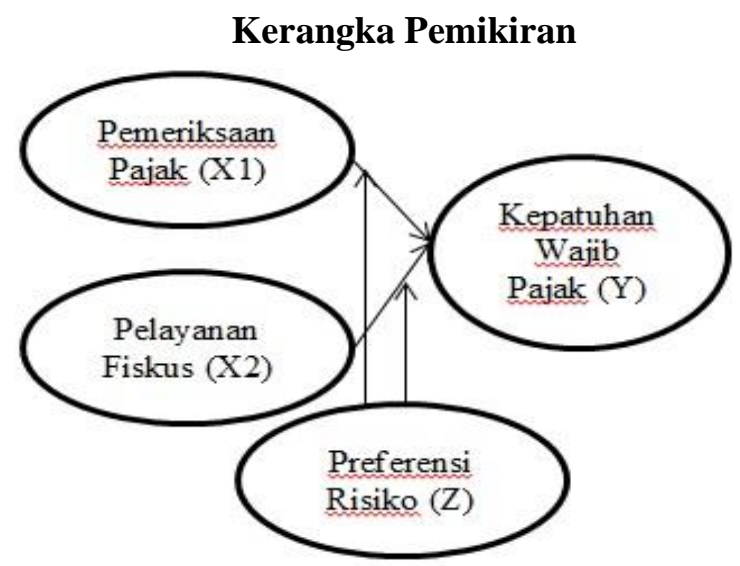

Gambar 1.

Model Peneliitian

\section{Pengembangan Hipotesis}

Dugaan sementara atau hipotesis diperoleh dan dirumuskan berdasarkan masalah dan kerangka pemikiran diatas sebagai berikut :

Program pemeriksaan pajak diharapkan pemerintah dapat menjalankan fungsi pengawasan terhadap wajib pajak agar sesuai peraturan perundang-undangan sehingga beban pajak untuk semua orang harus sama beratnya, artinya pajak harus dibayar sesuai dengan daya pikul masing-masing orang Resmi (2014).

H1: Berpengaruhnya hubungan secara langsung antara variabel pemeriksaan pajak Terhadap kepatuhan wajib pajak 
Teori atribusi (Heider, 1958) yang menyatakan tingkat kepatuhan wajib pajak berdasarkan dari faktor eksternal berupa pelayanan fiskus dan sanksi pajak yang menyatakan bahwa Para wajib pajak akan patuh dalam melaksanakan kewajiban perpajakannya tergantung bagaimana petugas pajak memberikan pelayanan kepada wajib pajak. Pemberian pelayanan yang baik kepada wajib pajak akan meningkatkan kepercayaan masyarakat dengan sendirinya, sehingga dapat meningkatan kepatuhan wajib pajak Yanto (2020).

H2: Berpengaruhnya hubungan secara langsung antara variabel pelayanan fiskus Terhadap kepatuhan wajib pajak

Berdasarkan teori prospek menurut Kahneman dan Tversky (1979) keputusan seorang wajib pajak dapat dipengaruhi oleh perilakunya terhadap risiko yang dihadapi. Preferensi risiko digunakan sebagai variabel moderating dimaksud memperkuat antara pemeriksaan pajak terhadap kepatuhan wajib pajak. Pemeriksaan pajak terhadap kepatuhan wajib pajak dapat dikatakan berpengaruh positif dan signifikan terhadap kepatuhan wajib pajak jika dimoderasi oleh preferensi risiko yang tinggi. Preferensi risiko seseorang merupakan salah satu komponen dari beberapa teori yang berhubungan dengan pengambil keputusan termasuk teori kepatuhan wajib pajak seperti teori prospek.

\section{H3: Preferensi risiko mampu menjadi pemoderasi hubungan antara pemeriksaan pajak} terhadap kepatuhan wajib pajak

Preferensi risiko memperkuat pengaruh persepsi wajib pajak tentang kualitas pelayanan fiskus terhadap kepatuhan wajib pajak orang pribadi, semakin tinggi wajib pajak menghendaki memilih risiko dan mengetahui jika suatu usaha atau penghasilan akan mengalami risiko kebangkrutan atau penurunan, mengetahui jika kesehatan seseorang tentu mempengaruhi dalam menjalankan berbagai aktifitas. Salah satunya aktifitas sebagai wajib pajak, mengetahui adanya perubahan kebijakan perpajakan yang dilakukan oleh pemerintah akan mempengaruhi Wajib Pajak dalam memenuhi kewajiban perpajakannya. Wajib pajak mengetahui perbedaan jenis maupun jabatan pekerjaan seseorang dapat memberikan perbedaan kepatuhan wajib pajak, maka hubungan pengaruh kualitas pelayanan fiskus terhadap kepatuhan wajib pajak orang pribadi akan semakin kuat Safitri (2018).

H4: Preferensi risiko mampu menjadi pemoderasi hubungan antara pelayanan fiskus terhadap kepatuhan wajib pajak

\section{METODE PENELITIAN}

Objek atau tempat yang dijadikan untuk penelitian ini yaitu di Kantor Pelayanan Pajak Pratama Surabaya Mulyorejo, dengan subjek dan populasi penelitian seluruh pajak Orang Pribadi (OP). Jenis non probability sampling dengan purposive sampling adalah sampel yang digunakan dalam penelitian ini. Data primer dan kuisioner merupakan teknik dalam mengumpulkan data dalam penelitian ini. Angket atau kuisioner merupakan instrument penelitian sebanyak delapan puluh tujuh (87) responden dengan kriteria Wajib Pajak Orang Pribadi Pengusaha Tertentu (WPOPT) berdasarkan Pajak Penghasilan (PPh) Pasal 25. Teknik analisis yang digunakan yaitu analisis GeSCA atau Generalized Structured Component Analysis.

\section{HASIL DAN PEMBAHASAN}

Berdasarkan hasil olah data statistic deskriptif menggunakan teknik analysis berdasar komponen berupa Generalized Structured Component Analysis atau GSCA menghasilkan uji validitas, reliabilitas dan optimalization global of fit yang sesuai standar yang ditetapakan. Nilai koefisian determinasi atau yang dikenal dengan R-Square sebesar 64.8\%. Koefisien jalur, standar error dan critical rasio djelaskn dalam tabel 1 mengenai model structural Generalized Structured Component Analysis sebagai berikut :

Tabel 2.

Output Uji Validitas dan Reliabilitas (Koefisien Jalur) GeSCA

\begin{tabular}{cc}
\hline \multicolumn{2}{c}{ Uji Validitas dan Reliabilitas } \\
\hline AVE & Cronbach Alpha \\
\hline 0,711 & 0,894 \\
\hline 0,799 & 0,936 \\
\hline 0,555 & 0,794 \\
\hline 0,566 & 0,842 \\
\hline
\end{tabular}

Sumber : Output GeSCA (Diolah) 
Berdasarkan tabel 2 tersebut dapat diketahui bahwa validitas memiliki nilai diatas 0,7 dan reliabilitas didapati memiliki nilai diatas 0.6 sehingga indikator yang mewakili variabel tersebut dikatakan valid dan dapat dihandalkan (reliabel).

Tabel 3.

Output Model Fit (Koefisien Jalur) GeSCA

\begin{tabular}{cc}
\hline \multicolumn{2}{c}{ Model Fit } \\
\hline FIT & 0.64 \\
\hline AFIT & 0.631 \\
\hline GFI & -1062.35 \\
\hline SRMR & 0.463 \\
\hline NPAR & 167 \\
\hline \multicolumn{2}{c}{ Sumber : Output GeSCA (Diolah) }
\end{tabular}

Berdasarkan tabel 3 tersebut dapat diketahui bahwa nilai Fit sebesar $0.640 \geq$ nilai cut off (sebesar 0.5) sehingga dapat dijelaskan bahwa kepatuhan wajib pajak dapat dijelaskan oleh indicator atau varian dari pemeriksaan pajak, pelayanan fiskus dan prefernsi risiko sebesar 64.0 persen, dan nilai AFIT sebesar 0.631 < FIT (sebesar 0.640), dengan demikian berdasarkan kriteria konstruk yang terbentuk dinyatakan sesuai atau layak. Indeks global optimalization GFI sebesar -1062.352 < nilai cut off (sebesar 0.9), dengan demikian berdasarkan kriteria, konstruk yang terbentuk dinyatakan belum sesuai atau belum layak. Nilai SRMR $0.463 \leq$ nilai cut off (sebesar 0.08) sehinggi dapat terindikasi bahwa tidak tidak ada perbedaan data yang dianalisa terhadap model, dan nilai NPAR sebesar 167, dengan demikian berdasarkan kriteria, konstruk yang terbentuk dinyatakan sesuai atau layak.

Tabel 4.

Output Model Struktural (Koefisien Jalur) GeSCA

\begin{tabular}{|c|c|c|c|}
\hline \multicolumn{4}{|c|}{ Path Coefficients } \\
\hline & Estimate & SE & CR \\
\hline $\mathrm{X} 1->\mathrm{Y}$ & -4.751 & 2.172 & $2.19^{*}$ \\
\hline $\mathrm{X} 2->\mathrm{Y}$ & 6.168 & 1.538 & $4.01^{*}$ \\
\hline Z->Y & 1.413 & 1.413 & 1 \\
\hline $\mathrm{X} 1 * \mathrm{Z}->\mathrm{Y}$ & 8.285 & 3.912 & $2.12^{*}$ \\
\hline $\mathrm{X} 2 * \mathrm{Z}->\mathrm{Y}$ & -10.235 & 2.55 & $4.01^{*}$ \\
\hline
\end{tabular}

Sumber : Output GeSCA (Diolah)

\section{PEMBAHASAN}

1. Pengaruh secara langsung (path analysis) antara pemeriksaan pajak terhadap kepatuhan wajib pajak memiliki nilai Critical Rasio (CR) sebesar 2.19 atau CR > 1.96 yang menunjukkan bahwa berpengaruhnya hubungan secara langsung antara variabel pemeriksaan pajak terhadap kepatuhan dalam menjalankan kewajiban perpajakan Ghozali \& Latan (2014). Artinya setiap wajib pajak yang dilakukan pemeriksaan pajak akan berdampak pada kepatuhan wajib pajak, semakin banyak wajib pajak yang diperiksa maka tingkat kepatuhan wajib pajak akan meningkat. Diharapkan dengan dilakukannya pemeriksaan terhadap wajib pajak dapat memberikan motivasi positif agar dapat meningkatkan kepatuhan wajib pajak. Hal ini sesuai dengan penelitian dari Mandagi (2014), Dewi (2017) dan Wahda (2018) menunjukkan bahwa pemeriksaan pajak berpengaruh terhadap tingkat kepatuhan dalam membayar dan melaporkan pajak.

2. Pengaruh secara langsung (path analysis) antara pelayanan fiskus terhadap kepatuhan wajib pajak memiliki nilai Critical Rasio (CR) sebesar 4.01 atau CR > 1.96 yang menunjukkan bahwa berpengaruhnya hubungan secara langsung antara variabel pemeriksaan pajak terhadap kepatuhan dalam menjalankan kewajiban perpajakan Ghozali \& Latan (2014). Pelayanan fiskus berperan penting dalam peningkatan kepatuhan wajib pajak, para wajib pajak akan patuh dalam melaksanakan kewajiban perpajakannya tergantung bagaimana petugas pajak memberikan pelayanan kepada wajib pajak. Pemberian pelayanan yang baik kepada wajib pajak akan meningkatkan kepercayaan masyarakat dengan sendirinya, sehingga dapat meningkatan kepatuhan wajib pajak (Yanto, 2020). 
Hasil penelitian sesuai dengan penelitian Yuslina (2018), Nur (2020) dan Yanto (2020) menyimpulkan bahwa pelayanan fiskus berpengaruh positif terhadap kepatuhan dalam membayar dan melaporkan pajak.

3. Pengaruh moderasi preferensi risiko atas pemeriksaan pajak terhadap kepatuhan wajib pajak memiliki nilai Critical Ratio (CR) sebesar 2.12 atau CR > 1.96 yang menunjukkan bahwa Preferensi risiko mampu menjadi pemoderasi hubungan antara pemeriksaan pajak terhadap kepatuhan dalam menjalankan kewajiban perpajakan Ghozali \& Latan (2014). Pemeriksaan pajak terhadap kepatuhan wajib pajak dapat dikatakan berpengaruh positif dan signifikan terhadap kepatuhan wajib pajak jika dimoderasi oleh preferensi risiko yang tinggi. Hasil penelitian ini sesuai dengan Teori Prospek Kahneman dan Tversky (1979) yang menjelasakan bahwa keputusan seorang wajib pajak dapat dipengaruhi oleh perilakunya terhadap risiko yang dihadapi karena setiap wajib pajak yang hendak menjalankan kewajiban perpajakannya akan patuh jika dilakukan pemeriksaan oleh aparat pajak dengan mempertimbangkan adanya risiko-risiko tertentu.

4. Pengaruh moderasi preferensi risiko atas pelayanan fiskus terhadap kepatuhan wajib pajak memiliki nilai Critical Ratio (CR) sebesar 4.01 atau CR > 1.96 yang menunjukkan bahwa Preferensi risiko mampu menjadi pemoderasi hubungan antara pelayanan fiskus terhadap kepatuhan dalam menjalankan kewajiban perpajakan Ghozali \& Latan (2014) semakin tinggi wajib pajak menghendaki memilih risiko dan mengetahui jika suatu usaha atau penghasilan akan mengalami risiko kebangkrutan atau penurunan, mengetahui jika kesehatan seseorang tentu mempengaruhi dalam menjalankan berbagai aktifitas. Salah satunya aktifitas sebagai wajib pajak, mengetahui adanya perubahan kebijakan perpajakan yang dilakukan oleh pemerintah akan mempengaruhi Wajib Pajak dalam memenuhi kewajiban perpajakannya. Wajib pajak mengetahui perbedaan jenis maupun jabatan pekerjaan seseorang dapat memberikan perbedaan kepatuhan wajib pajak, maka hubungan pengaruh kualitas pelayanan fiskus terhadap kepatuhan wajib pajak orang pribadi akan semakin kuat. Hasil penelitian ini sesuai dengan Ardyanto (2014) dan Safitri (2018) yang menyatakan bahwa preferensi risiko mampu memoderasi pengaruh pelayanan fiskus terhadap kepatuhan wajib pajak.

\section{KESIMPULAN}

Berdasarkan hasil dan pembahasan masing-masing variabel baik secara langsung maupun pengaruh moderasi maka peneliti dapat menyimpulkan bahwa:

1. Kepatuhan dalam menjalankan kewajiban perpajakan secara langsung dapat dipengaruhi oleh pemeriksaan pajak dengan hasil negatif dan signifikan. Setiap wajib pajak yang dilakukan pemeriksaan pajak akan berdampak pada kepatuhan wajib pajak, semakin banyak wajib pajak yang diperiksa maka tingkat kepatuhan wajib pajak akan meningkat. Diharapkan dengan dilakukannya pemeriksaan terhadap wajib pajak dapat memberikan motivasi positif agar dapat meningkatkan kepatuhan wajib pajak

2. Kepatuhan dalam menjalankan kewajiban perpajakan secara langsung dapat dipengaruhi oleh pelayanan fiskus dengan hasil positif dan signifikan. Pelayanan fiskus berperan penting dalam peningkatan kepatuhan wajib pajak, para wajib pajak akan patuh dalam melaksanakan kewajiban perpajakannya tergantung bagaimana petugas pajak memberikan pelayanan kepada wajib pajak. Pemberian pelayanan yang baik kepada wajib pajak akan meningkatkan kepercayaan masyarakat dengan sendirinya, sehingga dapat meningkatan kepatuhan wajib pajak.

3. Pemoderasi preferensi risiko memperlemah hubungan antara pemeriksaan pajak terhadap kepatuhan dalam menjalankan kewajiban perpajakan dengan jenis moderasi semu. keputusan seorang wajib pajak dapat dipengaruhi oleh perilakunya terhadap risiko yang dihadapi karena setiap wajib pajak yang hendak menjalankan kewajiban perpajakannya akan patuh jika dilakukan pemeriksaan oleh aparat pajak dengan mempertimbangkan adanya risiko-risiko tertentu.

4. Pemoderasi preferensi risiko memperlemah hubungan antara pelayanan fiskus terhadap kepatuhan dalam menjalankan kewajiban perpajakan dengan jenis moderasi semusemakin tinggi wajib pajak menghendaki memilih risiko dan mengetahui jika suatu usaha atau penghasilan akan mengalami risiko kebangkrutan atau penurunan, mengetahui jika kesehatan seseorang tentu mempengaruhi dalam menjalankan berbagai aktifitas. Salah satunya aktifitas sebagai wajib pajak, mengetahui adanya perubahan kebijakan perpajakan yang dilakukan oleh pemerintah akan mempengaruhi Wajib Pajak dalam memenuhi kewajiban perpajakannya 


\section{SARAN}

1. Saran Praktis :

- Bagi Direktorat Jenderal Pajak sebagai lembaga yang ditugaskan melaksanakan tugas pemungutan pajak khususnya KPP Pratama Surabaya Mulyorejo yang sudah melaksanakan tugasnya dengan sangat baik agar kedepannya terus dapat mempertahankan dan meningkatkan kepatuhan wajib pajaknya.

- Bagi wajib pajak disarankan senantiasa untuk selalu patuh terhadap kewajiban perpajakannya. Tingginya tingkat kepatuhan wajib pajak dalam membayar kewajiban pajaknya akan dapat meningkatkan pendapatan Negara yang nantinya akan digunakan kembali bagi kepentingan masyarakat untuk membiayai pembangunan dan meningkatkan kesejahteraan masyarakat.

\section{Saran Teoritis :}

- Bagi peneliti selanjutnya diharapkan akan lebih baik lagi jika memperluas sampel penelitian, seperti tidak hanya wajib pajak orang pribadi berdasarkan pasal 25 yang terdaftar di KPP Pratama Surabaya Mulyorejo saja namun diperluas menjadi seluruh wajib pajak orang pribadi maupun badan yang terdaftar di KPP Pratama Surabaya Mulyorejo atau daerah lainnya.

\section{REFERENSI}

Ardyanto, Arif Angga, Nanik Sri Utaminingsih, (2014). "Pengaruh Sanksi Pajak Dan Pelayanan Aparat Pajak Terhadap Kepatuhan Wajib Pajak Dengan Preferensi Risiko Sebagai Variabel Moderasi". Accounting Analysis Journal. Semarang : FE UNNES, ISSN 2252-6765.

Aryobimo Tri, Putut dan Nur Cahyonowati, (2012). Pengaruh Persepsi Wajib Pajak tentang Kualitas Pelayanan Fiskus terhadap Kepatuhan Wajib Pajak dengan Kondisi Keuangan Wajib Pajak dan Preferensi Risiko sebagai Variabel Moderating (Studi Empiris terhadap Wajib Pajak Orang Pribadi di Kota Semarang). Dipenegoro Journal of Accounting, Volume 1, No. 1, Tahun 2012, hal 2.

Dewi, A. K., Darmansyah., \& Djadang, S, (2017). "Antecedent terhadap Kepatuhan Wajib Pajak Badan Dengan Tax Amnesty Sebagai Pemoderasi”. JIAFE (Jurnal Ilmiah Akuntansi Fakultas Ekonomi) Volume 3 No. 1 Tahun 2017, Hal. 49-61.E-ISSN 2502-4159.

Direktorat Jenderal Pajak. Rasio Pajak Di Indonesia Tahun 2015-2019. http://www.pajak.go.id.

Heider, Fritz, (1958). The Psychology of Interpersonal Relations. New York: Wiley.

Ghozali, Imam, \& Latan Hengky. (2014). Partial Least Squares : Konsep, Teknik dan Aplikasi Menggunakan SmartPLS 3.0 (edisi ke-2). Semarang : Universitas Diponegoro

Jatmiko, (2006). Pengaruh Sikap Wajib Pajak pada Pelaksanaan Sanksi Denda, Pelayanan Fiskus, dan Kesadaran Perpajakan Terhadap Kepatuhan Wajib Pajak Studi Empiris Terhadap Wajib Pajak Orang Pribadi di Kota Semarang. Unisversitas Diponegoro: Tesis Megister Akuntansi.

Kahneman, Daniel dan Amos Tversky,(1979). Prospect Theory: An Analysis of Decision Under Risk. Econometrica, vol. 47, pp.263-291.

Mandagi, Chorras, (2014). "Pengaruh Pemeriksaan Pajak Terhadap Tingkat Kepatuhan Wajib Pajak Badan Dalam Memenuhi Kewajiban Perpajakannya Pada Kpp Pratama Manado", Jurnal EMBA. Vol.2 No.3 September 2014, Hal. 1665-1674. ISSN 2303-1174.

Nur, Mulyani, (2020). "Pengaruh Sikap Rasional, Pelayanan, Dan Pemahaman Peraturan Pajak Terhadap Tingkat Kepatuhan Wajib Pajak Dengan Preferensi Risiko Sebagai Variabel Moderating". Prosiding Seminar Nasional, ISSN (P) : 2615 - 2584.

Resmi Siti, (2014). Perjakan Teori dan Kasus Edisi 4. Jakarta: Salemba Empat.

Safitri, (2018). "Pengaruh Pelayanan Fiskus, Kesadaran Wajib Pajak, Pemahaman Perpajakan Terhadap Kepatuhan Wajib Pajak Yang Dimoderasi Kondisi Keuangan Dan Preferensi Risiko (Studi Empiris pada Wajib Pajak Orang Pribadi yang Terdaftar di Kantor Wilayah Direktorat Jenderal Pajak Jawa Tengah I)". Tesis. Magister Akuntansi STIE Dharmaputra Semarang.

Siti Kurnia Rahayu, (2017). Perpajakan Indonesia: Konsep Dan Aspek Formal. Jakarta : Graha Ilmu. Tingkat Kepatuhan Wajib Pajak Orang Pribadi Tahun 2015-2020 (Survey pada Kantor Pelayanan Pajak Pratama Surabaya Mulyorejo). 
Jurnal Proaksi, 8 (2), Hal. 451 - 459

Wahda, Bagianto, Yuniati. (2018). "Pengaruh Pemeriksaan Pajak Melalui Kepatuhan Wajib Pajak Dan Dampaknya Terhadap Efektivitas Penerimaan Pajak Penghasilan Badan”. Vol. III No. 1 Januari - Juni 2018, p-ISSN: 2541-5255.

Yanto, Iksan, Hastuti, (2020). "Pengaruh Tax Amnesty, Pengetahuan Perpajakan dan Pelayanan Fiskus Terhadap Kepatuhan Wajib Pajak". Journal of Economic Business and Governance Challenges 2019, October 03, Indonesia, 2020 EAI DOI 10.4108/eai.3-10-2019.2291943.

Yuslina, Tanjung, dan Silfi, (2018).’Pengaruh Pelayanan Fiskus, Pengetahuan Perpajakan dan Kesadaran Wajib Pajak Terhadap Kepatuhan Wajib Pajak dengan Kondisi Keuangan dan Preferensi Resiko Wajib Pajak Sebagai Variabel Moderating (Study Empiris pada Wajib Pajak Orang Pribadi di Kota Pekanbaru)". Jurnal Akuntansi \& Manajemen, Vol 13, No. 2 -. 